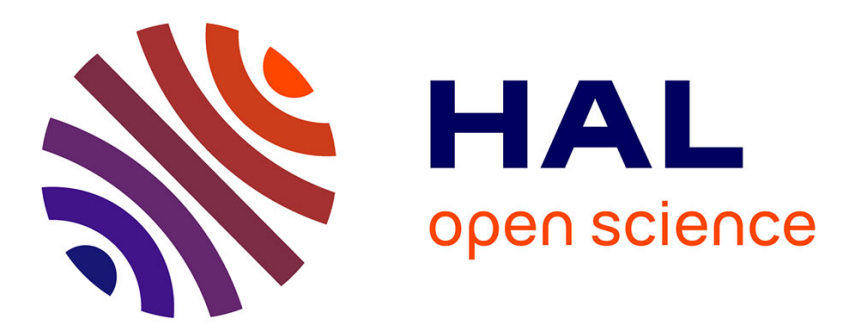

\title{
Investigation of Oxidation Kinetics in Nonstoichiometric Ni-Zn Ferrites
}

\author{
V. Fetisov, G. Kozhina, A. Fetisov, A. Fishman, V. Mitrofanov
}

\section{To cite this version:}

V. Fetisov, G. Kozhina, A. Fetisov, A. Fishman, V. Mitrofanov. Investigation of Oxidation Kinetics in Nonstoichiometric Ni-Zn Ferrites. Journal de Physique IV Proceedings, 1997, 07 (C1), pp.C1-221C1-222. 10.1051/jp4:1997183 . jpa-00255130

\section{HAL Id: jpa-00255130 https://hal.science/jpa-00255130}

Submitted on 1 Jan 1997

HAL is a multi-disciplinary open access archive for the deposit and dissemination of scientific research documents, whether they are published or not. The documents may come from teaching and research institutions in France or abroad, or from public or private research centers.
L'archive ouverte pluridisciplinaire HAL, est destinée au dépôt et à la diffusion de documents scientifiques de niveau recherche, publiés ou non, émanant des établissements d'enseignement et de recherche français ou étrangers, des laboratoires publics ou privés. 


\title{
Investigation of Oxidation Kinetics in Nonstoichiometric Ni-Zn Ferrites
}

\author{
V.B. Fetisov, G.A. Kozhina, A.V. Fetisov*, A.Ya. Fishman** and V.Ya. Mitrofanov** \\ Ural State Economic University, 62, 8 March str., 620219 Ekaterinburg, Russia \\ * Institute of Solid State Chemistry, UrO RAN 91, Pervomaiskaya str., 620218 Ekaterinburg, Russia \\ ** Institute of Metallurgy, UrO RAN 101, Amundsen str., 620016 Ekaterinburg, Russia
}

\begin{abstract}
The distinctive features of kinetics and oxidation mechanisms in the ferrites $\mathrm{Ni}^{2+}(0.5862) \mathrm{Zn}^{2+}(0.0891) \mathrm{Co}^{2+}(0.019) \mathrm{Fe}^{2+}(0.2057) \mathrm{Fe}^{3+}(2) \mathrm{O}^{2-}(4)$ are investigated by methods of thermogravimetry, differential thermal analysis, calorimetry, radiography etc. The new data indicative of the influence of the morphological defect structure peculiarities on the oxidation reaction of nonstoichiometric nickel-zinc ferrites are obtained.
\end{abstract}

\section{INTRODUCTION}

The single phase solid solution is formed during the process of high-temperature sintering of nonstoichiometric ferrites, which is capable to preserve the high stability in the metastable state during the process of cooling in the oxide medium (the air atmosphere) [1]. The metastable state is characterized by different degree of oxidation depending on the cooling rate. Under the heating of such a ferrite in air the reaction of low-temperature reoxidation of single spinel phase is going on at first and then separation of $\alpha-\mathrm{Fe}_{2} \mathrm{O}_{3}$ phase is observed.

The mechanism and kinetics of these processes have been investigated both for massive samples [1] and finely dispersed powders $(40-60 \mathrm{~nm})[2,3]$. It is established that the oxidation process is determined by the diffusion of cations to the crystal surface. It should be noted also that the selective oxidation of different ions depending on its charge and type of occupied sites in the spinel structure is discovered.

In the present publication the peculiarities of the oxidation kinetics of ferrites in the range 400 to $650^{\circ} \mathrm{C}$ are investigated. Nickel-zinc ferrite with a slight addition of cobalt ions and excess of $\mathrm{Fe}_{2} \mathrm{O}_{3}$ phase has been chosen as an object of investigation.

\section{EXPERIMENT}

Let us consider that during the high-temperature sintering $\left(1300-1320^{\circ} \mathrm{C}\right)$ the excess $\mathrm{Fe}_{2} \mathrm{O}_{3}$ phase is dissociated up to $\mathrm{Fe} \mathrm{O}_{4}$ with its successive dissolution in the spinel phase. Then the cation distribution in the spinel lattice are given by formula

$$
\mathrm{Ni}{ }^{2+}(0.5862) \mathrm{Zn}^{2+}(0.1891) \mathrm{Fe}^{2+}(0.2057) \mathrm{Co}^{2+}(0.0190) \mathrm{Fe}^{3+}(2) \mathrm{O}^{2-(4)}
$$

The ferrite samples (1) were realized by the annealing at $\mathrm{T}=1000^{\circ} \mathrm{C}$ and oxygen pressure $10^{-3}-10^{-2}$ atm. during 0.5 hour with later hardening in the forevacuum. It has been established from radiography and microstructural data that all the samples were single phase spinels with the crystal lattice parameter $8.372 \pm 0.001 \mathrm{~A}$. Fragment of the ionic configuration showing the distribution of $\mathrm{Fe}^{2+}$ ions among the non-equivalent crystal lattice positions can be written as $\left(\mathrm{Fe}^{2+}(\lambda)\right)\left[\mathrm{Fe}^{2+}(0.2067-\lambda)\right]$, where parameter $\lambda$ denotes the degree of inversion.

The oxidation of ceramic and powder samples were performed under the continuous heating and isothermal conditions in a Du Pont-2000 in the range 400 to $600^{\circ} \mathrm{C}$ and oxygen pressure $p=0.21 \mathrm{~atm}$. Oxidation kinetic curves of ceramic samples are depicted in Fig. 1. It is easy to see the peculiarity in the vicinity of $\mathrm{T}=512^{\circ} \mathrm{C}$ where the mass increase with temperature undergoes a discontinuous change. It should be noted that the mass variation rate (DTG curves) in the same temperature region when a nickel - zinc spinel was heated at a constant rate of $2^{\circ} \mathrm{C} / \mathrm{min}$ are charactarized by two distinct peaks at $\mathrm{T}=$ 510 and $550^{\circ} \mathrm{C}$. 


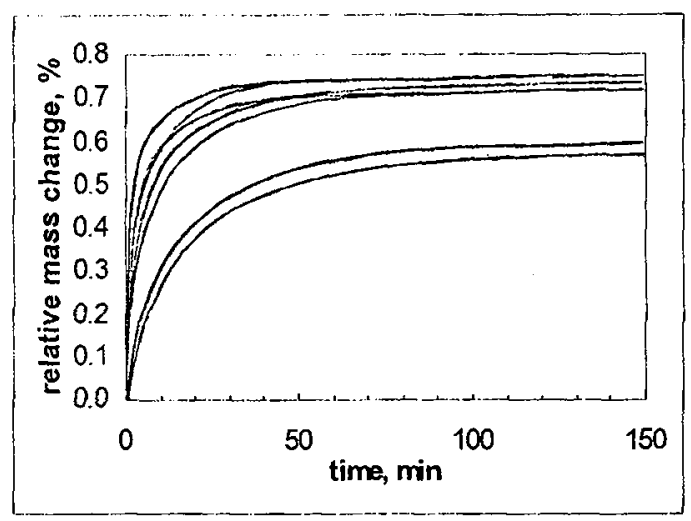

Fig. 1

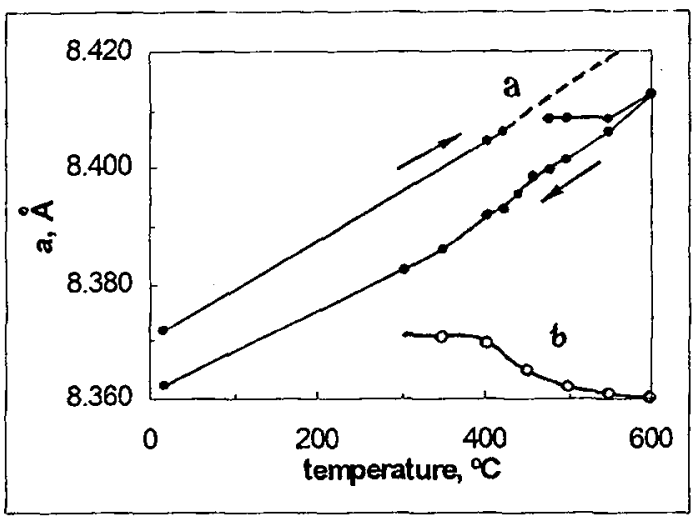

Fig. 2

Fig. I. Kinetic (TG) curves for $\mathrm{T}=500,510,515,520,525,540,560^{\circ} \mathrm{C}$ (from bellow to upwards).

Fig. 2. Dependence of lattice parameter on temperature (a) and hardening from "quasi-equilibrium" state (b).

High-temperature and usual radiography data show that the oxidation of ferrite (1) occurs without violation of solid phase homogeneity and is accompanicd by sufficient decrease of the crystal lattice parameter. The high-temperature radiography data are reported in Fig. 2. The survey of each point in Fig. 2 was realized during 10-15 min. in the isothermal conditions. The heating and cooling processes were performed at a constant rate of $15^{\circ} \mathrm{C} / \mathrm{min}$. The dotted line shows the total change crystal lattice parameter due to both thermal cxpansion and variation of cation distribution. The results of investigations on quenched "quasi-equilibrium" sample states are reported in Fig. 2 (curve 2).

\section{DISCUSSION}

The obtained results seem to indicate that the oxidation process of ferrite (1) in the single phase region can be described by the following reaction

$$
\begin{gathered}
\mathrm{M}^{2+}(0.7943) \mathrm{Fe}^{2+}(0.2057) \mathrm{Fe}^{3+}(2) \mathrm{O}^{2-}(4)+\mathrm{mO}(2)= \\
=\mathrm{t}\left(\mathrm{M}^{2+}(0.7943 / \mathrm{t}) \mathrm{Fe}^{2+}((0.2057-4 \mathrm{~m}) / \mathrm{t}) \mathrm{Fe}^{3+}((2+4 \mathrm{~m}) / \mathrm{t})[(1.5 \mathrm{~m} / \mathrm{t}) \mathrm{O}(4),\right.
\end{gathered}
$$

where $\mathrm{t}=1+0.5 \mathrm{~m} ; \mathrm{M}$ denotes $\mathrm{Ni}, \mathrm{Zn}$ and $\mathrm{Co}$ ions which don't participate in the oxidation process; $\square$ is the cation vacancy.

The observed peculiarity of system behaviour in the vicinity of $T^{*}$ (Fig. 1) can't be explained well by the selective oxidation of $\mathrm{Fc}^{2+}$ ions in octa-and tctrapositions [3]. Such a process assumes the relatively rigid "fixing" of $\mathrm{Fe}^{2+}$ ions in the tctrapositions at $\mathrm{T} \approx \mathrm{T}^{*}$, what is expected to be less probable for $\mathrm{T}^{*} \approx 500^{\circ} \mathrm{C}$. The experimental conditions dictate rather high mobility of iron ions. In this case both the oxidation of $\mathrm{Fe}^{2+}$ ions and redistribution of cations among tetra-and octapositions take place. From the beginning of the oxidation reaction the transfer of the tetrahedral $\mathrm{Fe}^{2+}$ ions to the octahedral positions (tip to total) originates, at least, under the "cquilibrium" oxidation of ferrite (1).

The behaviour of the kinetic oxidation curves can be explained, if we take into account the presence of two types of defect formations and corresponding to them strain states in the considered ferrites. The variation of the morphology of defect structure occurs at the temperature $\mathrm{T} \approx 512^{\circ} \mathrm{C}$. The direct manifestation of this fact is supported by the observed change of etching figures inside the grains with the temperature increase. The etching figures has globular form for the lowtemperature modification ( $\mathrm{T}<\mathrm{T}^{*}$ ) and platc-like form - for the high-temperature modification ( $\mathrm{T}>\mathrm{T}^{*}$ ).

It is interesting to note that the tempcrature $T^{*}$ is close to the Curie temperature $\left(T_{C}\right)$ of the investigated ferrite.

\section{Acknowledgements}

We gratefully acknowledge assistance in taking of high-temperature radiography measurements by R.G.Zaharov and S.A.Pctrova. This work was supported by the Russian Fond for Fundamental Investigations under the grant N 96-03-32106.

\section{References}

[1] Tretyakov Yu.D., Oleinikov N.N., Granik V.A., Physic-chemical foundations of thermal treatment of ferrites (MGU, Moscow, 1973) pp. 1-203 (in Russian).

[2] Gillot B., Kharroubi M., Metz R., et al, J.Solid State Chem. 91 (1991) 375-384.

[3] Gillot B., J.Solid State Chem. 113 (1994) 163-167.

[4] Gillot B., Ann.Chem.Fr. 3 (1978) 209-219. 